\title{
Clinical Trial Insurance in Serbia
}

\author{
Zlatko A. Žagar
}

MARFI-PE Insurance Broker Co. Ltd. Belgrade

\section{SUMMARY}

Prior the commencement of the clinical trial in Serbia the Sponsor is obliged to provide the insurance policy covering the patient's bodily injury and damaged health caused by the clinical trial.

According to provisions of Serbian Insurance law insurance polices have to be issued by the insurance companies established in Serbia. Every insurance policy not issued by the insurance company established in Serbia shall be deemed as null and void. The only exceptance, is when the foreign clinical trial liability policy is stipulated that the insurance contract acknowledges the jurisdiction of Serbian domestic courts and other Serbian authorities to decide on damage claims (that never happend in Serbian practice).

The Sponsor will fulfill this obligation stipulated in Serbian law when provides the Clinical Trial Liability policy issued by the Serbian insurance company. Nowadays, few of Serbian inusrance companies are issuing such polices.

Under the clinical trial liability insurance cover the insureds are: Sponsor, Medical Centers in Serbia performing or controlling the clinical trial, Principal Investigators and their assistant staff performing or controlling the clinical trial. The beneficiaries of the insurance cover are patients and/or members of their families - inheritresses. The insurance company will indemnify the beneficiary mentioned in the policy when the insured event occurred i.e. when occurred bodily injury, psychic disease and alienation, psychic damages, illnesses and deaths caused by the clinical trial.

The amount of indemnity by the insurance company to the beneficiaries is limited by the amount of sum insured per occurrence and/or by the total amount of the sum insured for the total period of the insurance cover. According to case-law in Serbia the total sum insured between EUR 500.000 and EUR 1.000.000 is considered as sufficient so far to indemnify the patients in case of the insured event.

If an insurance event occurs the benefits provided by the insurance company shall cover the following: non-financial losses of the claimant; financial benefits lost by the claimant; costs necessary for the elimination of the non-financial and financial losses of the claimant; costs of litigation.

Serbian Law on Obligations stipulates that claims of the policy holder or third party are time bared for three years, reckoning from the first day upon expiration of the calendar year in which a claims was caused. If the interested party proves that until date defined in above paragraph it was not aware that insured event had happened, the time bar period commences from the day of awarnes, but in any case a claim is time bared for five years, reckoning from the first day upon expiration of the calendar year in which a claims was caused.

Keywords: clinical trials, research, investigator, patients insurance, regulations 


\section{INTRODUCTION}

Within the comprehensive Clinical Trials procedure in Serbia the very important issue and theme is insurance of Participants taking part in Clinical Trial. There are still no literatures, expert's analyzes or clinical trial insurance guidelines in Serbia covering this theme. Our intention with the text bellow is to pay attention to some important aspects of this issue and furthermore to help and assist various sponsors (mainly from the abroad), clinical research organizations, medical centers, principal investigators, patients, authorities and other persons or entities involved in Clinical Trials in Republic of Serbia to arrange adequate insurance policy in accordance with the Serbian Law.

\section{METHODOLOGY}

In this text the author has used positive Serbian law an regulations and insurance conditions issued by Serbian insurance companies.

\section{TOPIC}

\section{Stipulations of the Law in Serbia as regards of Insurance of Patients included in Clinical Trials in Serbia}

Generally, as stipulated in Serbian Insurance Law ("Official Gazette of the Republic of Serbia” No. 55/2004, 70/2004, 61/2005, 61/2005other Law, 85/2005-other Law and 101/2007, 107/2009, 99/2011, 119/2012 and 116/2013) the property and personal insurance in Serbia are voluntary [1]. As an exception from that provision, the insurance of property and persons is compulsory in cases regulated by the law [2]. In new Serbian Insurance Law ("Official Gazette of the Republic of Serbia" No. 139/2014) which will apply from June 26, 2015 these stipulations are not modified [3].

Based on such provision of the Insurance Law the Insurance of Patients included in Clinical Trials in Serbia is stipulated in other laws and articles as an compulsory insurance.

Law on Medical Products and Medical Devices ("Official Gazette of the Republic of Serbia" No. 30/2010) provides thatthe sponsor of a clinical trials Prior to the commencement of a clinical trial, must insure the persons subjected to the clinical trials in case damages occur as to the health of those persons, where the damage is caused by the clinical trial of medicinal product, pursuant to the Law, as well as to determine by the contract the amount of necessary costs that belong to the persons participating in the clinical trial. Sponsor of clinical trials of veterinary medicinal products must specify in the contract the amount of compensation to be paid to the animal owners, in case of the damage caused by the clinical trial [4].

Law on Patients' rights ("Official Gazette of the Republic of Serbia" No. 45/2013) stipulates that the Medical Center in Serbia, prior to the commencement of a clinical trial, must insure the persons subjected to the clinical trials in case damages occur as to the health of those persons, all in accordance with Serbian Law [5].

Ordinance on Content of Claims or Documentaion for Approval of Clinical Trials of Medicaments and Medical Devices, as well as on the Procedure of Clinical Trials of Medicaments and Medical Devices ("Official Gazette of the Republic of Serbia" No. 64/2011 and No. 91/2013) stipulates that Documentation for approval of Clinical Trials includes the Evidence that the sponsor has insured all $\mathrm{Pa}$ tients included inthe clinical trials in the event of damage to their health within the period of the clinical trial [6] and that prior to the commencement of clinical trials the Sponsor has insured all Patients included in Clinical Trial, in accordance with the law, for the case of damage to the health of patients, caused by the clinical trial [7].

\section{Where to arrange Clinical Trial insurance?}

Insurance Law of Serbia stipulates that Property and Persons in the Republic of Serbia can only be insured with the insurance companies established in compliance with that Law ie. with the insurance companies registered in the Republic of Serbia after approval of National bank of Serbia [8]. All insurance contracts concluded contrary to this Article are null and void [9].

As an exception from this stipulation property and persons can be insured with a foreign insurance company if insurance against that kind of risk is not conducted in the Republic of Serbia, and other property and persons prescribed by the Government of the Republic of Serbia [10].

In new Serbian Insurance Law Law ("Official Gazette of the Republic of Serbia” No. 139/2014) 
which will apply from June 26, 2015 these stipulations are not basically modified [11].

In 2006 the Government fo Serbia had issued Decree on Property and Persons That May be Insured with a Foreign Insurance Company ("Official Gazette of the Republic of Serbia" No. 47/2006). This Decree stipulates that Persons requesting an approval of a competent authority of the Republic of Serbia for clinical testing of medications and medicaments, and for placing medicaments of foreign producers in sale, in conformity with the law governing medications and medicaments, may take out insurance against liability for damage sustained as a consequence of application of such medications or medicaments with a foreign insurance company, on condition that the insurance contract acknowledges the jurisdiction of domestic courts and other authorities to decide on damage claims [12]. This stipulation never applied in praxis in Serbia due to the prescribed condition that the insurance contract acknowledges the jurisdiction of domestic courts and other authorities to decide on damage claims. Foreign insurance companies are not willing to accept the jurisdiction of Serbian courts as part of their insurance polices and insurance conditions.

Therefore, within the territory of Serbia, Clinical Trial Insurance polices are issuing by domestic insurance companies registered at authorities in Republic of Serbia.

\section{Possibility of cooperation with foreign insur- ance companies}

There are few possibilities for foreign insurance companies to take part in covering the clinical trial risk in Serbia.

a) Generally, the clinical trial insurance policy issued by the insurance company not registered in Serbia is null and void, except when in the policy is stipulated that the insurance contract acknowledges the jurisdiction of domestic courts and other authorities to decide on damage claims, as provided for in Decree on Property and Persons That May be Insured with a Foreign Insurance Company ("Official Gazette of the Republic of Serbia" No. 47/2006).

b) The foreign insurance company can form and establish an insurance company in Serbia. That company will be domestic insurance company and can lagally issue clinical trial polices. Nowadays, there are few such insurance companies registered in Serbia (UNIQA insurance company Belgrade, AXA Insurance company Belgrade, Generali Insurance Company Serbia, Wiener Stadtische Insurance Company Belgrade etc..).

c) If the risk specified in clinical trial policy is over the self insured retention of domestic insurance company, than the risk over the self insured retention can be placed in reinsurance abroad, through one of four reinsurance companies in Serbia: Dunav Re, Generali Re Serbia, Novi Sad Re and Wiener Re Serbia [13].

However "fronting" polices are against the Srbian insurance Law ("Official Gazette of the Republic of Serbia" No. 55/2004, 70/2004, 61/2005, 61/2005-other Law, 85/2005-other Law and 101/2007, 107/2009, 99/2011, 119/2012 and 116/2013) which stiupulates:

- The self insured retention of the insurance company is the amount of the risks undertaken by the contract, which the company it self keeps at all times, and which it can cover by its own means [14] (the total limit of indemnity of EUR 500.000 and even of EUR 1.000.000 with lower limits per occurrence are within the self insured retention of all better insurance companies in Serbia) and

- Authorized persons in an insurance company, insurance brokerage company, insurance agencies, agencies providing other insurance services, enterprises or other legal entities with special purpose departments for providing other insurance services, as well as insurance agents, who on the occasion of risk and claims assessment draft a false assessment and statement shall be sentenced for a criminal offense to a fine or imprisonment of up to three years [15].

The similar stipulations are in new Serbian Insurance Law Law ("Official Gazette of the Republic of Serbia" No. 139/2014) which will apply from June 26, 2015 [16].

Furthermore, insurance companies registered in Serbia must apply only their own insurance conditions and tariffs previously adopted by their Board and thereafter submitted within 15 days to National Bank of Serbia attached with positive actuarial opinion [17]. The National Bank of Serbia is entitled to withdraw from an insurance company the business license if the insurance company fails to act in accordance with these stipulations and apply not legally adopted insurance conditions and tariffs and/or if not previously submitted their insurance conditions and tariffs attached with actuarial positive opinion to National Bank of 
Serbia within 15 days from the adoption by the Board [18].

Aside of stipulations in Serbian Insurance Law which do not allow so called "fronting" polices, the "fronting" polices are not recommended for implementation in clinical trial insurances in Serbia, as well. One of the reasons is that the reinsurance conditions submitted by the foreign reinsurer to domestic company can be contradictory to the imperative stipulations of the Serbian positive law. For example, if the reinsurance contract provides "claims made" insurance cover such stipulation will be considered as null and void due to imperative stipulations of domestic Law on Obligation which provides "claims occurrence“ insurance cover [19].

\section{Insurance policy covering clinical trial as requiering in Serbian Law}

Insurance policy required by the Serbian law is world known Clinical Trial Liability policy.

With the inception of the Clinical Trial Liability policy the Insurer (insurance company registered in Serbia) is covering the compensation obligation of the Insured in respect of losses caused to the Trial Subject (Patients) in the course of clinical trials performed or sponsored by the Insured, for which the Insured is liable and obliged to pay compensation according to the legal rules of the Republic of Serbia [20].

Insured is the institution or company sponsoring or performing the clinical trial, whose name is indicated in the policy [21].

If the Insured in the policy only sponsors such trial, but the trial is performed by other medical institution(s), for the purpose of this insurance than the medical institutions, employees of the institution(s) (principal investigators and his/her assistant staff) performing or controlling the trial, shall be deemed to be co-insureds [22].

Trial Subject is an individual patient or non-patient volunteer who after signing the Informed Consent participates in the clinical trial [23].

Patient and non-patient volunteer are not insureds. They are beneficiaries of the insurance policy. Insureds are: sponsor, medical institutions in Serbia, employees of those institution/s (principal investigators and theirs assistant staff) performing and controlling the clinical trial and sometimes the isnured is clin- ical researsch organization (CRO), as well.

\section{Insurance Events}

Insurance events are:

a) Death or permanent injury to health of the Trial Subject caused by the investigational medical product under trial

b) Death or permanent injury to health of the Trial Subject, caused directly by his/her perticipation in the clinical trial [24].

\section{Insurance cover}

If an insurance event occurs the benefits provided by the Insurance Company shall cover the following:

- non-financial losses of the claimant;

- financial benefits lost by the claimant;

- costs necessary for the elimination of the non-financial and financial losses of the claimant;

- costs of litigation and legal defence approved by the Insurance Company in advance [25].

Generally Clinical Trial Liability Insurance policy is covering rights for indemnity as specified in Serbian Law on Obligation [26].

\section{Exclusions from the insurance cover}

The indemnification obligation under the clinical trial liability insurance generally is not covering the following:

- any claims arising from circumstance(s) or occurrence(s) which has been notified under any Policy or Certificate of Insurance attaching prior to the inception of this Policy,

- losses arising from the fact that the investigational medical product did not meet the expectations or did not produce the expected beneficial results,

- in the cases when the study includes the trial (testing) of a medical product, no indemnification is paid to the Trial Subject who did not receive such during the trial, except

a) if the loss arises from the fact that in the interest of the trial, other medical products or treatments that otherwise would be used for the mitigation of the given illness or condition, were withheld, or

b) if the placebo having been given to the Trial Subject makes the refusal of the indemnification to be unreasonable,

- claims directly or indirectly caused by or contributed to by or arising from ionising ra- 
diation or radioactive contamination by radioactivity from any nuclear fuel or any nuclear waste from the combustion of any nuclear fuel; or from the radioactive, toxic, explosive or other hazardous properties of any explosive nuclear assembly or nuclear component thereof,

- any losses caused by or in consequence of:

a) war, invasion, acts of foreign enemies, hostilities or warlike events (whether war be declared or not), civil war,

b) permanent or temporary seizure, resulting from confiscation, military appropriation or requisition on the order of a legal authority,

c) riot, strike, rebellion, separatist action, military or civil appraisal, insurrection, counterrevolution, revolution, military or usurped power, martial law or any other event or reason the declaration of which entails the introduction of martial law,

d) terrorist action committed by any organisation or any person or persons acting on behalf or in connection with such organisations.

- If the Insured (the Policyholder) failed to comply with his/her reporting obligation outlined in the policy, and therefore substantial circumstances became concealed.In the case of breach of the reporting and change reporting obligation determined in the policy, the liability of the Insurance Company shall not arise, unless it is proved that the circumstance so concealed or not reported was known to the Insurance Company at the conclusion of the contract or they did not interfere with the occurrence of the insurance event [27].

\section{Limit of Indemnity - Sum Insured}

Serbian law does not prescribe the Limit of Indemnity - Sum Insured of the required insurance cover.

However, in practice, it is required by local Ethic Committees in each Medical Centre in Serbia and by the Central Committee at Medicine and Medical Devices Agency of Serbia that the minimum Limit of Indemnity - Sum Insured is EUR 500.000 for Phase III and IV of the clinical trial and bioequivalence Phase and EUR 1.000.000 for Phases I and II of the clinical trail. If the Limit of Liability - Sum Insured is lower, than the policy can be rejected by the committee in charge in Serbia.

There is no need for arrangement of much higher Limit of Indemnity - Sum Insured for clinical trial insurance in Serbia. Due to pres- ent court practice in Serbia, Limit of Indemnity - Sum Insured over EUR 2.000.000 is not necessary.

\section{Time Bar Period for Insurance Contract}

Serbian Law on Obligation stipulates that Claims of the policy holder, or third party in the case of life insurance contract, are time bared for five, and for other insurance contracts for three years, reckoning from the first day upon expiration of the calendar year in which a claims was caused [28].

If the interested party proves that until date defined in above paragraph it was not aware that insured event had happened, the time bar period commences from the day of awarnes, but in any case a claim is time bared, for the life insurance contract for ten, and for other insurance contracts for five years, from the day defined in above paragraph [29].

Claim of the minor without legal representative and other person without representative, cannot be time barred before expiration of two years from the time when that persons became completely legally capable or from the time they obtained representative [30].

The above are imperative stipulations and any modification and/or cancellation of them in the policy or in the policy wording is null and void.

\section{Rules of compensation and amount of in- demnification}

Clinical Trial Liability Insurance conditions stipulates that:

- The Insurer Company shall indemnify the beneficiary for losses up to the limit amount for any one event and for annual aggregate (limit of indemnity) stated in the Schedule forming part of the contract.

- All reimbursements shall be paid by the Underwriter in a lump sum.

- The amount of compensation payable shall be appropriate to the nature, severity and persistence of the injury. It should be assessed with reference to the measure and quantum of damages that would have been awarded by the courts of the country where Trial took place at the date on which the compensation is assessed for a substantially similar injury.

- Compensation shall not be denied or abated by reason of any participation of a third party in causing the damage for which such third 
party can be made liable (joint liability), but following the settlement of the claim the Trial Subject's rights against such third party shall be subrogated to the Insurer.

- The amount of the compensation shall be paid by the Insurer to the Trial Subject within fourteen days from the date of the receipt of the loss occurence notification. If some period of time is necessary for establishing the existance of the obligation of the Insurer and for the amount of such obligation, the above mentioned period of fourteen days shall commence from the date when such obligation and its amount is established. If the amount of obligation of the Insurer would not have been established within the above specified period of fourteen days, than the Insurance company must, on the request of the beneficiary/Trial Subject, pay the amount of the uncontested part of its obligation as the advance payment.

- In connection with any claims against the Insured, the Insurer may at any time pay the Insured the amount equalling the Limit of Indemnity or any lesser amount for which such claims can be settled and thereupon the Insurer shall relinquish the control of such claims and be under no further liability in connection therewith except for the costs and expenses that the Insurer has already agreed to bear in respect of matters, prior to the date of such payment [31].

\section{Deductibles}

Deductibles are often stipulated in Clinical Trial Liability polices in Serbia. However, if deductibles are higher than $20 \%$ minumum EUR 2.000 per loss, than such policy can be rejected by the local authorities (Ethic Committees). Therefore, it would be much better if deductibles are not part of the policy or if the insurance cover is concluded with certain deductibles, than it is better to stipulate in the policy that the Insurer shall compensate the beneficiary / Trial Subject in whole amount applying no deductibles and in such case the Insured is obliged to compensate the Insurer the part of the loss od damage up to the amount of so paid deductible/s [32].

\section{Insurance brokers - their position and importance in arranging Clinical Trial Po- lices in Serbia}

Many of Clinical Trial Liability Insurance po- lices in Serbia are concluded and issued using engagements of the insurance brokers. Activities of the insurance bokers in Serbia are stipulated in Serbian Insurance Law ("Official Gazette of the Republic of Serbia" No. 55/2004, 70/2004, 61/2005, 61/2005-other Law, 85/2005-other Law and 101/2007, 107/2009, 99/2011, 119/2012 and 116/2013) still applying [33] and in new Serbian Insurance Law ("Official Gazette of the Republic of Serbia" No. 139/2014) which will apply from June 26, 2015 [34].

Insurance brokerage activities include activities related to connecting the insured and/or policy holder with an insurance company, in order to negotiate the conclusion of an insurance contract, based on the order of the insurance company established in compliance with the provisions of this Law or based on the order of the insured, and/or policyholder [35].

Insurance brokerage activities, as the sole type of activity, are conducted by an insurance brokerage company licensed by the National Bank of Serbia to carry out those activities [36].

Therefore, foreign insurance brokers not registered in Serbia and without a license obtained from National Bank of Serbia can not conduct their brokerage activities in Serbia.

The task of the insurance broker is to: - provide expertise and advise to the Client/ Insured in respect of required and necessary insurance, assessment of the risk, the scope of the cover and insurance conditions;

- obtain the insurance offers from one or more of the insurance companies and negotiate with them to obtain the best possible insurance conditions and accaptable (as lower as possible) insurance premium;

- present and explain to the Client/Insured all obtained insurance offers and suggest the acceptance of the best insurance offer/insurance company amongst them acceptable for local ethic committees and central Agency;

- after the issuance of the policy provide all necessary advices and assistance to the Client/ Insured and in case of any loss off or damage assist and advise the Insured in respect of assessment of the damage and submission of the claim [37].

All services provided by the insurance broker to the Insured are free of charge for the Insured. The insured who engaged the insurance broker has no obligation to pay to the insurance broker any fee, commission, charges 
or expanses neither if the insurance contract is concluded nor if the negotiations failed and the policy is not issued.

In Serbia there are few insurance brokers familiar with clinical trial liabiulity insurances and it is recommended to sponsors and other insureds to engage one of them.

\section{CONCLUSION}

Clinical trial insurance is compulsory insurance in Serbia.

Insurance policy required by the Serbian law is world known Clinical Trial Liability policy.

The policy has to be issued by the insurance company registered in Serbia, except if in the foreign insurance policy is specified that the insurance contract acknowledges the jurisdiction of Serbian domestic courts and other Serbian authorities to decide on damage claims. However, foreign insurance companies are not willing to accept the jurisdiction of Serbian courts and other Serbian authorities as part of their insurance polices and insurance conditions.

There are few insurance companies in Serbia which are issuing clinical trial insurance polices in accordance with Serbian Law. Fronting polices are not allowed in Serbia and generally not recommended, as well.

Limit of Indemnity - Sum Insured in Serbia is still very low comparing to limits in West European countries and in USA. In practice, it is required by local Ethic Committees in each Medical Centre in Serbia and by the Central Committee at Medicine and Medical Devices Agency of Serbia that the minimum Limit of Indemnity - Sum Insured is EUR 500.000 for Phase III and IV of the clinical trial and bioequivalence Phase and EUR 1.000.000 for Phases I and II of the clinical trail. Otherwise, the policy can be rejected and the trial postponed.

It is recommended to Sponsors and other Insureds to engage the local insurance broker to arrange clinical trial liability insurance for them for the particular trial. There are few Serbian insurance brokers which can finalize whole procedure and obtained proper Clinical Trial Liability policy in Serbian and in English language within 2-5 days.

\section{REFERENCES}

1. Article 6. paragraph 1. of Serbian Insurance Law ("Official Gazette of the Republic of Serbia" No. 55/2004, 70/2004, 61/2005, 61/2005-other Law, 85/2005-other Law and 101/2007, 107/2009, 99/2011, 119/2012 and 116/2013), http://www.nbs.rs/internet/english/20/zakoni. html

2. Article 6. paragraph 2. of Serbian Insurance Law ("Official Gazette of the Republic of Serbia" No. 55/2004, 70/2004, 61/2005, 61/2005-other Law, 85/2005-other Law and 101/2007, 107/2009, 99/2011, 119/2012 and 116/2013),

http: //www.nbs.rs/internet/english/20/zakoni. html

3. Article 4. of the new Serbian Insurance Law ("Official Gazette of the Republic of Serbia" No. 139/2014),

http://www.nbs.rs/internet/english/20/zakoni. html

4. Article 72. of Law on Medical Products and Medical Devices ("Official Gazette of the Republic of Serbia” No. 30/2010),

http://www.alims.gov.rs/eng/regulations/law-onmedicines-and-medical-devices/

5. Article 25. paragraph 9. of Law on Patients' rights ("Official Gazette of the Republic of Serbia" No. 45/2013)

6. Article 6. paragraph 1. point 18 of Ordinance on Content of Claims or Documentaion for Approval of Clinical Trials of Medicaments and Medical Devices, as well as on the Procedure of Clinical Trials of Medicaments and Medical Devices ("Official Gazette of the Republic of Serbia" No. 64/2011 and No. 91/2013),

http://www.alims.gov.rs/eng/regulations/rulesfor-medicinal-products/

7. Article 26. paragraph 1. point 4 of Ordinance on Content of Claims or Documentaion for Approval of Clinical Trials of Medicaments and Medical Devices, as well as on the Procedure of Clinical Trials of Medicaments and Medical Devices ("Official Gazette of the Republic of Serbia" No. 64/2011 and No. 91/2013)

8. Article 7. paragraph 1. of Serbian Insurance Law ("Official Gazette of the Republic of Serbia" No. 55/2004, 70/2004, 61/2005, 61/2005-other Law, 85/2005-other Law and 101/2007, 107/2009, 99/2011, 119/2012 and 116/2013),

http://www.nbs.rs/internet/english/20/zakoni. html

9. Article 7. paragraph 2. of Serbian Insurance Law ("Official Gazette of the Republic of Serbia" No. 55/2004, 70/2004, 61/2005, 61/2005-other Law, 85/2005-other Law and 101/2007, 107/2009, 99/2011, 119/2012 and 116/2013),

http://www.nbs.rs/internet/english/20/zakoni. html

10. Article 7. paragraph 3. of Serbian Insurance 
Law ("Official Gazette of the Republic of Serbia" No. 55/2004, 70/2004, 61/2005, 61/2005-other Law, 85/2005-other Law and 101/2007, 107/2009, 99/2011, 119/2012 and 116/2013), http://www.nbs.rs/internet/english/20/zakoni. html

11. Article 20. paragraph 1. and Article 3. of the new Serbian Insurance Law ("Official Gazette of the Republic of Serbia" No. 139/2014),

http://www.nbs.rs/internet/english/20/zakoni. html

12. Article 2. of Decree on Property and Persons That May be Insured with a Foreign Insurance Company ("Official Gazette of the Republic of Serbia" No. 47/2006)

http://www.nbs.rs/internet/english/20/osg/index.html

13. Article 15. paragraph 1., 2., 3. and 4. of Serbian Insurance Law ("Official Gazette of the Republic of Serbia" No. 55/2004, 70/2004, 61/2005, 61/2005other Law, 85/2005-other Law and 101/2007, 107/2009, 99/2011, 119/2012 and 116/2013) and Article 20. paragraph 1., Article 3 paragraph 2. and Article 7. paragraph 1., 2., 3., 4. and 5. of the new Serbian Insurance Law ("Official Gazette of the Republic of Serbia" No. 139/2014),

http://www.nbs.rs/internet/english/20/zakoni. html

14. Article 15. paragraph 2. of Serbian Insurance Law ("Official Gazette of the Republic of Serbia" No. 55/2004, 70/2004, 61/2005, 61/2005-other Law, 85/2005-other Law and 101/2007, 107/2009, 99/2011, 119/2012 and 116/2013), http://www.nbs.rs/internet/english/20/zakoni. html

15. Article 224. of Serbian Insurance Law ("Official Gazette of the Republic of Serbia" No. 55/2004, 70/2004, 61/2005, 61/2005-other Law, 85/2005other Law and 101/2007, 107/2009, 99/2011, $119 / 2012$ and 116/2013),

http://www.nbs.rs/internet/english/20/zakoni. html

16. Article 7. paragraph 2. and Article 258. of the new Serbian Insurance Law ("Official Gazette of the Republic of Serbia" No. 139/2014),

http://www.nbs.rs/internet/english/20/zakoni. html

17. Article 58. paragraph 1. and paragraph 2. point 1 and Article 156. paragraph 1. point 6 and paragraph 2. of Serbian Insurance Law ("Official Gazette of the Republic of Serbia" No. 55/2004, 70/2004, 61/2005, 61/2005-other Law, 85/2005-other Law and 101/2007, 107/2009, 99/2011, 119/2012 and 116/2013) and Article 67. paragraph 1. and Paragraph 2. point 1 and Article 177. paragraph 1. Point 6 of the new Serbian Insurance Law ("Official Gazette of the Republic of Serbia" No. 139/2014), http://www.nbs.rs/internet/english/20/zakoni. html

18. Article 174. paragraph 1. point 12 of Serbian Insurance Law ("Official Gazette of the Republic of
Serbia" No. 55/2004, 70/2004, 61/2005, 61/2005other Law, 85/2005-other Law and 101/2007, 107/2009, 99/2011, 119/2012 and 116/2013) and Article 214. paragraph 1. point 16 of the new Serbian Insurance Law ("Official Gazette of the Republic of Serbia" No. 139/2014), http: //www.nbs.rs/internet/english/20/zakoni. html

19. Articles 376 - 380 of Law on Obligations Published in the Službeni list SFRJ, No. 29/78 of 26 May 1978; Amendments in Nos. 39/85 of 28 July 1985, $45 / 89$ of 28 July 1989 (YCC) and 57/89 of 29 September 1989; Final amendments in the Službeni list SRJ, No. 31/93 of 18 June 1993 ,

http: / / www.mpravde.gov.rs/files/The\%20Law\%20 of\%20Contract\%20and\%20Torts_180411.pdf>

20. Article I. of Clinical Trial Liability Insurance conditions issued by UNIQA Non-Life Insurance Company Belgrade on March 8,2012

21. Definitions in Clinical Trial Liability Insurance conditions issued by Energoprojket Garant NonLife Insurance Company Belgrade on November 23, 2007

22. Definitions in Clinical Trial Liability Insurance conditions issued by Energoprojket Garant NonLife Insurance Company Belgrade on November 23, 2007

23. Definitions in Clinical Trial Liability Insurance conditions issued by Energoprojket Garant NonLife Insurance Company Belgrade on November 23, 2007

24. Article II. of Clinical Trial Liability Insurance conditions issued by UNIQA Non-Life Insurance Company Belgrade on March 8, 2012

25. Article IV. of Clinical Trial Liability Insurance conditions issued by UNIQA Non-Life Insurance Company Belgrade on March 8, 2012

26. Articles 185-205 of Law on Obligations Published in the Službeni list SFRJ, No. 29/78 of 26 May 1978; Amendments in Nos. 39/85 of 28 July 1985, $45 / 89$ of 28 July 1989 (YCC) and 57/89 of 29 September 1989; Final amendments in the Službeni list SRJ, No. 31/93 of 18 June 1993,

http: / /www.mpravde.gov.rs/files/The\%20Law\%20 of\%20Contract\%20and\%20Torts_180411.pdf>

27. Articles $V$ and $\mathrm{VI}$ of Clinical Trial Liability Insurance conditions issued by UNIQA Non-Life Insurance Company Belgrade on March 8, 2012

28. Article 380 paragraph 1 . of Law on Obligations Published in the Službeni list SFRJ, No. 29/78 of 26 May 1978; Amendments in Nos. 39/85 of 28 July $1985,45 / 89$ of 28 July 1989 (YCC) and $57 / 89$ of 29 September 1989; Final amendments in the Službeni list SRJ, No. 31/93 of 18 June 1993,

http: //www.mpravde.gov.rs/files/The\%20Law\%20 of\%20Contract\%20and\%20Torts_180411.pdf>

29. Article 380 paragraph 2. of Law on Obligations Published in the Službeni list SFRJ, No. 29/78 of 
26 May 1978; Amendments in Nos. 39/85 of 28 July $1985,45 / 89$ of 28 July 1989 (YCC) and 57/89 of 29 September 1989; Final amendments in the Službeni list SRJ, No. 31/93 of 18 June 1993,

http://www.mpravde.gov.rs/files/The\%20Law\%20 of $\% 20$ Contract $\% 20$ and\%20Torts_180411.pdf>

30. Article 385. of Law on Obligations Published in the Službeni list SFRJ, No. 29/78 of 26 May 1978; Amendments in Nos. 39/85 of 28 July 1985, 45/89 of 28 July 1989 (YCC) and 57/89 of 29 September 1989; Final amendments in the Službeni list SRJ, No. 31/93 of 18 June 1993 ,

http: / / www.mpravde.gov.rs/files/The\%20Law $\% 20$ of $\% 20$ Contract\%20and\%20Torts_180411.pdf >

31. Article $X$ of Clinical Trial Liability Insurance conditions issued byEnergoprojket Garant Non-Life Insurance Company Belgrade on November 23 ,2007

32. Article XI of Clinical Trial Liability Insurance conditions issued by UNIQA Non-Life Insurance Company Belgrade on March 8, 2012

33. Articles 72-86 of Serbian Insurance Law ("Official Gazette of the Republic of Serbia" No. 55/2004, 70/2004, 61/2005, 61/2005-other Law, 85/2005-other Law and 101/2007, 107/2009, 99/2011, 119/2012 and 116/2013),

http://www.nbs.rs/internet/english/20/zakoni. html

34. Articles 85-96 of the new Serbian Insurance Law ("Official Gazette of the Republic of Serbia" No. 139/2014),

http://www.nbs.rs/internet/english/20/zakoni. html

35. Article 72 of Serbian Insurance Law ("Official Gazette of the Republic of Serbia" No. 55/2004, 70/2004, 61/2005, 61/2005-other Law, 85/2005other Law and 101/2007, 107/2009, 99/2011, 119/2012 and 116/2013),

http://www.nbs.rs/internet/english/20/zakoni. html

36. Article 73. paragraph 1. of Serbian Insurance Law ("Official Gazette of the Republic of Serbia" No. 55/2004, 70/2004, 61/2005, 61/2005-other Law, 85/2005-other Law and 101/2007, 107/2009, 99/2011, 119/2012 and 116/2013),

http://www.nbs.rs/internet/english/20/zakoni. html

37. Article 84. of Serbian Insurance Law ("Official Gazette of the Republic of Serbia" No. 55/2004, 70/2004, 61/2005, 61/2005-other Law, 85/2005other Law and 101/2007, 107/2009, 99/2011, $119 / 2012$ and 116/2013) and Article 94. of the new Serbian Insurance Law ("Official Gazette of the Republic of Serbia” No. 139/2014),

http://www.nbs.rs/internet/english/20/zakoni. html 


\title{
Osiguranje kliničkih ispitivanja u Srbiji
}

\author{
Zlatko A. Žagar
}

MARFI-PE Insurance Broker Co. Ltd. Beograd, Srbija

\section{KRATAK SADRŽAJ}

Pre početka kliničkih ispitivanja u Srbiji zakonska je obaveza sponzora da obezbedi polisu osiguranja koja bi pacijentima koji se podvrgavaju kliničkim ispitivanjima obezbedila novčanu nadoknadu u slučaju povrede tela ili zdravlja kao posledice kliničkih ispitivanja.

Saglasno odredbama važećeg Zakona o osiguranju Republike Srbije polise osiguranja se moraju ugovarati kod društava za osiguanje osnovanih u Republici Srbiji. Svaki ugovor o osiguranju zaključen suprotno ovim odredbama je ništav. Jedini izuzetak je ukoliko je u stranoj polisi za osiguranje od odgovornosti prilikom kliničkih ispitivanja izričito navedeno da je tim ugovorom o osiguranju prihvaćena nadležnost domaćih srpskih sudova i drugih organa Republike Srbije koji odlučuju o zahtevima za naknadu štete (što se do sada nikada nije desilo u praksi u Srbiji).

Ova zakonska obaveza se postiže ugovaranjem polise osiguranja od odgovornosti prilikom kliničkih ispitivanja lekova (Clinical Trial Laibility Policy). Ovakve polise osiguranja izdaje nekoliko osiguravajućih društava u Srbiji.

Kod ove vrste osiguranja osiguranici su sponsor, zdravstvene ustanove gde se vrše klinička ispitivanja, glavni istraživači koji sprovode klinička istraživanja i njihovi asistenti. Korisnici naknade iz osigurnja su pacijenti i/ili njihove porodice (naslednici). Obaveza osiguravajućeg društva po ovim uslovima osiguranja nastaje kada se desi osigurani slučaj odnosno kada usled kliničkog ispitivanja leka dodje do povrede tela, psihičke i duševne bolesti, psihičkih oštećenja, oboljenja, invalidnosti, šoka, bolesti ili bolešću izazvane smrti.

Obaveza osiguravača ograničena je limitom pokrića po jednom osiguranom slučaju i/ili godišnjim limitom pokrića. Imajući u vidu dosadašnju sudsku praksu u Republici Srbiji iznos od EUR 500.000 do EUR 1.000 .000 u dinarskoj protivvrednosti može se smatrati za sumu osiguranja koja za sada zadovoljava zahteve ispunjenja obaveze o zaključenju ovog osiguranja.

Ukoliko dođe do slučaja za koji je predviđeno osiguranje, Osiguravajuća Kompanija treba da pokriva sledeće: materijalne i nematerijalne štete/gubitke oštećenoga, tj. korisnika osiguranja; izgubljenu finansijsku dobit oštećenoga, tj. korisnika osiguranja; troškove neophodne za odstranjivanje nematerijalnih i materijalnih gubitaka oštećenoga, tj. korisnika osiguranja; parnične troškove.

Zakon o obligacionim odnosima propisuje da su rokovi za podnošenje odštetnih zahteva prema osiguravajućim društvima tri godine, računajući od prvog dana posle proteka kalendarske godine u kojoj je potraživanje nastalo. Ako zainteresovano lice dokaže da do dana određenog u prethodnom stavu nije znalo da se osigurani slučaj dogodio, zastarevanje počinje od dana kad je za to saznalo, s tim da u svakom slučaju potraživanje zastareva za pet godina računajući od prvog dana posle proteka kalendarske godine u kojoj je potraživanje nastalo.

Ključne reči: klinička ispitivanja, osiguranje pacijenata, regulativa, istraživač 